\title{
The Concept of Tawhid in visual Artworks
}

\author{
Nuratikah Abu Hassan, Ponirin Amin and Suhaimi Tohid
}

\begin{abstract}
Before the coming of Islam, Malay societies professed animism. These situations totally switched and transformed after the advent of Islam that brought the concept of Tawhid (monotheism) and this situation has shifted and have dismissed the concept of polytheism. Starting with the concept of the oneness of God and the worship of Islam has fascinated wide interest in the local community and different field especially in visual art approaches. The concept of the paper, alongside with its content, appropriate methods and finding, is conceptual and philosophical. Therefore, this paper is to identify the concept of Tawhid (the Oneness of Allah) through visual artworks in Malaysia. Furthermore, to analyze the selected samples of visual artworks in used a theory of criticism by Edmund Burke Feldman (1980) to proven the artworks is stresses with a principles of Islamic art; Tawhid concept. Qualitative methods are applied in this study and it based on the process of gather the data analysis form the literature within the context of Islamic art that focused on the concept of Tawhid and interlink to the visual analysis artwork. Indeed, the outcome of this study is to go in depth that visual artworks as a medium for artists to bring the audience closer to the creator through the concept of Tawhid
\end{abstract}

\section{Keywords - Concept; Tawhid; Visual artworks}

\section{INTRODUCTION}

Islam religion fundamentally controls the relationship between man and God, man and man, and man and universe. Islamic basic law which must be held by Muslim is based on the Qur'an and the Sunnah. Nevertheless, in respect to culture and arts, the Islamic law would be flexible but still based on the law of Islam, where the use of figurative art is prohibited and not allowed in art and culture. However, a search for Malay art values seems to have become a new dimension with the Islamic revivalist.

The justification given for Malay proclivity / Muslim community related to the presence Tawhid concept or 'Unity'. For Malay/Muslim artists, the idea of Tawhid will brings a peace as a true guideline to build of the community (Ummah) or the perfect society with a trust and stability. One advantage associated with the reconstruction of the spiritual realm are stronger and more inward in line with world-view pertaining to Islamic teachings inspired by 'magnificent' of a past Islamic civilization.

Nuratikah Abu Hassan, Faculty of Art \& Design, MARA University of Technology, 40450 Shah Alam Selangor, Malaysia, iekahssan@gmail.com Ponirin Amin, Faculty of Art \& Design, MARA University of Technology, 40450 Shah Alam Selangor, Malaysia, poniebamin@live.com

Suhaimi Tohid, Faculty of Art \& Design, MARA University of Technology, 40450 Shah Alam Selangor , Malaysia, mieetohid@hotmail.co.uk
When this situation is reached, there will exist a balance and harmony on this earth, thus bring artistic values in the sense of beauty, perfection and truth. This is the basis for the true nature of art or even the cosmos, the existence of harmony and justice in the complexity of behavior, speech, emotion, thoughts and human intellect. Indeed, harmony and balance is the essence of Tawhid or Unity of the Godhead to create, manage and govern Islamic art the noblest and highest as stated by Ismail al-Faruqi, "In Aesthetic is the expression of Tawhid."

The idea of monotheism is an expression of the beautiful values (idea of beauty) which is objective, transcendent, mystical, and inexpressible, and the idea of beauty (idea of beautifulness) that are subjective, expressive, and cultural understanding. The thought of al-Faruqi shows that literary arts, calligraphy ornaments, music, and the art of space are inseparable from the monotheism in the Islamic worldview. Similarly, Buya Hamka, Tawhid is a concept which symbolizes the belief of monotheism in Islam who believes that God is one Essence that creates controls and regulates the universe is Allah Subhanahu wa ta'ala, called the rububiyyah God. Rububiyyah faith is a belief that is recognized even by the unbeliever. Indeed, faith as a way of life that is reflected in every human action that is the goal of unity [1]. Thus, this study is to identify the concept of Tawhid (the Oneness of Allah) through visual artworks in Malaysia. On the other hand, to analyze the selected samples of visual artworks, used the theory of criticism by Edmund Burke Feldman (1980) to prove the artworks, with principles of Islamic art; Tawhid concept.

\section{METHOD APPROPRIATION}

The research is based on broad approach:

1. To identify the Tawhid concept in visual artworks used a theory by Edmund Burke Feldman (1980) (Analysis selected visual artworks in Malaysia)

The investigation of the particular objective consists of the following steps as outlined below: 
To discuss the concept of Tawhid according to Islamic philosophy

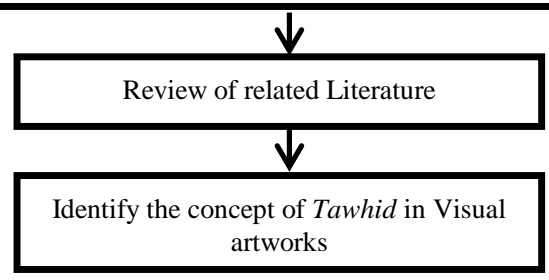

To describe, analysis, interpretation, and judgment- Selected Visual artworks (Theory Edmund Burke Feldman)

\section{$\downarrow$}

Finding and Conclusion

Fig. 1 The flowchart that shows the methods and process.

\section{ON THE CONCEPT OF TAWHID}

\section{a) Tawhid Concept (God's Oneness) in Islamic View}

The concept of tawhid (also called Tawheed and Tauheed) which the most significant element in the Islamic arts. Tawhid means stressing the concept of unity or oneness of Allah. Based on the concept of Tawhid, Muslims have faith in that God cannot be held equal in any way or grade to any other being or concept, He only One and deserve to be worshipped. It is obvious by the pronouncement of the Shahadah in Islam "La ila ha illa Allah" which means (there is no God only Allah) the Oneness of God. Similarly with the view by the great scholar of Islam, Ibn al- Arabi mentioned that Allah has stated thirty-six times in the Holy book of Qur'an, He is the only truly divine God (Tahwid). Thus, anyone who puts his faith and trust in Allah filled with the names and attributes it will receive blessings from Him [2].

Geometry is an important design in the Islamic architecture. Particularly, in the Islamic designs, geometry represents the principles of harmony, order and beauty. It obviously exists in the design of plans, façade, ornament and patterns. It expresses many concepts of Islam for instance the unity and the Oneness of Allah the perfection and the infinity of creation in the universe, the containments and the continuity [3]. Study by [4] mentioned that, the similar finding about the implication of Tawhid in the Islamic architecture has symbolizes the identity Islamic architecture are conspicuous and touch on the beauty of the soul.

\section{b) Character and Characteristic of Tawhid Concept}

Islam is founded on Tawhid, the unity of God, monotheism as generally known in the West and it is often repeated in the holy Quran as the fundamental doctrine of Islam. Furthermore, in bringing out the characteristic features of Islamic monotheism in perspicuous terms, Tawhid or Islamic monotheism is expressed in a formula called al-Shahadah " $\mathrm{La}$ ila ha illa Allah" (there is no God but Allah [5]. Islam put absolute emphasis on the unity of God and everything else revolves round this centre and derives from it. It begins with God and ends in Him. In addition, this related with the process of human cycle life, we are created from God and when we death we will return to Him. In the same way, this apparently simple formula forms the dividing line between Iman (true belief in God) and Kufr (disbelief), because of this principle of Tawhid, the Islamic belief in God is considered to Unitarian and Islam counted all over the world's monotheism religion. Indeed, the principle of Tawhid is profound that needs further explanation even among Muslims [6]. Obviously, three categories of Tawhid are commonly referred to by the following title which is Tawhid ar-Rububiyah ("Maintaining the unity of Lordship") that is, affirming that Allah is only the one, without partners. Second, Tawhid al-Asma, was-sifat ("Maintaining the unity of Allah's names and Attributes,") that is, affirming that they are incomparable and unique. The last, the Tawhid al-Ibadah ("Maintaining the unity of Allah's worship") that is affirming that Allah is alone in His right to be worshipped. The Qur'an is clear on Allah's Oneness in the Surah Al-Ikhlas (Verse 112 in Holy Qur'an) means "Oneness" the means every verse of Surah means 1: He is Allah (who is) One, 2: The called upon, 3: Who has not given birth, and has not been born, 4:There is none equal to Him [7].

\section{c) Concept of Tawhid in Visual Artworks}

Geometrically structured two dimensional decorative patterns consisted not only of abstract geometric shape, but included inscription and vegetal designs organized according to rules of regular geometry. In addition, these design of motifs clearly appeared on the Malay/Islamic art. The previous study by [8] has pointed that the basis and the determining factor underlying the Malay traditional art is based on the concept of Tawhid, Oneness of God and a Unity, which subsumes diversity, variety and multiplicity. On the other hand, she also addressed the attitudes of the Malay craftsman in woodcarving towards reality, philosophy, aesthetics and the creative process. In study Jihad in the context of visual arts, explains that Al-Quran provides guidance and guideline to mankind where its completeness contains high dignitaries value incomparable to men's creation. "Allah is beautiful and $\mathrm{He}$ loves beauty" (Hadith Bukhari) the effort to revive art according to Islamic perspective measured as "Jihad" in the journey to identify beauty and to get closer and know Allah [9]. Indeed, art considered as a something that has aesthetic values, in Islamic art is constituted to Allah is defined as a beauty.

The teachings of monotheism or unity in Islam preferentially expressed in various stages of human life as the unity of humanity, the unity of the universe, the unity of human civilization and unity of the human race. The concept of monotheism has implications to our lives as human beings, both at the individual and society, the arts field also has the concept of unity of faith which brings artists to get closer to the sentiments of Islamic. In creating artworks it is understood that Islam forbids such forms, because to uphold the most sublime idea, the Tawhid concept (unity). Therefore, how can we express the idea of unity in the visual artworks? One approach that is emphasized in Islam is through geometry. "Geometric expression" happens to be one of the simplest expressions of unity in the cosmos. Therefore, it is said that 
Islamic art is more on mathematics, physic, especially geometry. In the analysis of selected artworks has found that most of Malay/Islamic artist used a Geometric shape to show the concept of Tawhid (Oneness of Allah).

\section{SULAIMAN ESA}

Sulaiman Esa known as Islamic artist with convey the elements of Islamic arts in his artworks. Through artworks 'Mahsuri II in Figure 1 embraced the traditional Malay aesthetic principles such as refinement, contrast,unity, useful and symbolism pointed by Zakaria Ali, theory of Malay beauty concept (1989) inspired by the 'kepala kain' (main design) of a sarong, refer to Figure 3, decorated with bamboo shoot motifs in striking colours employing Malay aesthetic principles with colourful ornamentations as the core of the spiritual expression embedded in the final form of the art. Obviously, the bamboo shoot motifs in triangle shape are represented the concept of unity that stresses in the Malay traditional art such as woodcarving, batik, and songket. The bamboo shoot (Pucuk Rebung), the geometric patterns created with hand-made paper, metal threads and bamboo are reminiscent of decorations of Islamic architecture or traditional batik motifs. Indeed, the artwork is represents a fusion of Islamic Malay tradition and western modernistic abstract painting. On the other hand, it symbolizes the Tawhid concept through the representations of the geometric shape in the artworks. [10] Explained that the main factor contributed to the most significant transformation in traditional Malay art was the Islamic concept of tawhid (Oneness of Allah) as embodied in the proclamation of the Al-shahaadah, (There is no God the Ultimate and Absolute Reality who is transcendent and inexpressible.

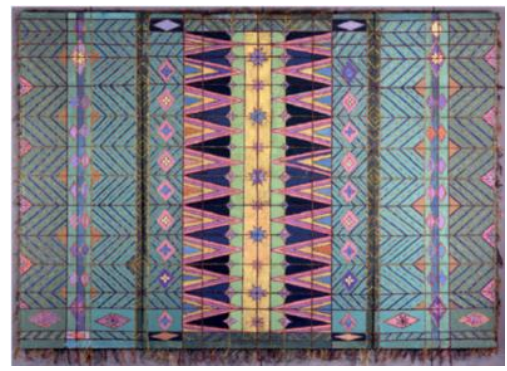

Fig 1: Sulaiman Esa, 'Mahsuri II', mixed media. (Source: collection of Fukuoka Museum, Japan.)

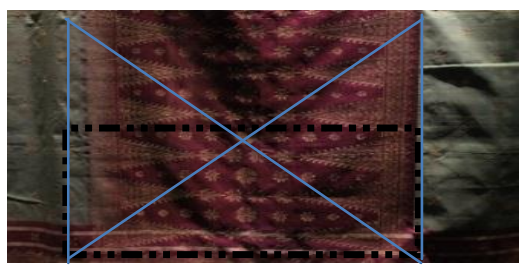

Fig 1.1: Motif Pucuk Rebung in Sarawak Songket. The image is gather from the Muzium Textile Kuala Lumpur. Photo by Nuratikah Abu Hassan, 2015.

\section{PONIRIN AMIN}

Parallel artworks bring a Tawhid concept by Ponirin Amin, the famous Malaysian artist in Printmaking, through his artwork Yasin (1989), the artist is sensitive and aware with the Godhead issues. Clearly, in his artworks, he is strive to give the awareness to the people especially the Muslim about the Holy book of Qur'an, as human one day will return to our creator (death). Indonesian artist, AD Pirous, [11] mention that human life is dividing into three stages, the first one is the birth, the life and the last is the death. The concept of geometric pattern is much closed with the concept of Malay/ Islamic values. For instance, the form of geometric pattern is arranged in harmonious composition to relate with the rhythm of dhikr form in abstract expression. Indeed, the geometric shape represents Tawhid concept (the oneness of God) and Unity through the cubic shape, the image of Kaaba (Holy Kaaba). In addition, the image of calligraphy words from the Surah Yasin (verse 2-4).The meaning of the verse is:

\section{Verse 2: In the Qur'an, full of wisdom \\ Verse 3: indeed thou (Muhammad) was one of the Rasul \\ Verse 4: on the straight path}

The artist wants the audience to think and appreciate the verses of the holy Quran that are in the artwork. It does not only look beautiful, but it also can attract Muslim audience to embrace the work and indirectly those who know the Surah will directly to read it. Indeed, it is bring the audience get closer to the Almighty (Allah S.W.T).

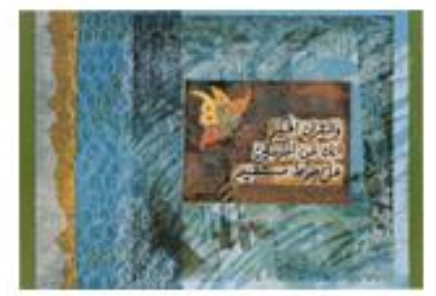

Fig. 2: Yasin (1989), Ponirin Amin, Silkscreen.

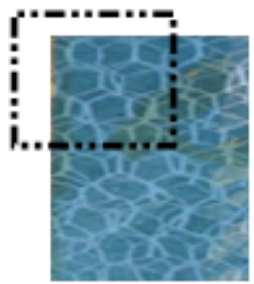

Fig. 2.1: The close up image geometric Cubic form

\section{SYED AHMAD JAMAL}

The triangular shape has become a symbol that can carry various meanings according to its position in the structure of the composition. The famous Malaysian artist, Syed Ahmad Jamal in his artwork Semangat Ledang (1999) in Figure.3, constantly used the geometric form which is triangle shape. Obviously, it also symbolizes the stage of Muslim human life that consists of seven layers of sky and earth, related with the 
seven layers of heaven. Furthermore, the triangular shape in the Semangat Ledang also synonym with Malay traditional motifs: Pucuk Rebung (bamboo shoot). This motif constantly used in the design and ornament Malay traditional arts, for instance, in woodcarving, batik and songket. [12] mentioned that, Pucuk Rebung motif reflects the knowledge and the cosmological belief of the Malays about the spiritual world and the real world. Furthermore, these particular motifs would always pointed to one (Oneness of God) concept of Tawhid, the major components in Islam which is Sufism. The definition of explains that a spirit is something intangible that is the opposite of corporeal form.
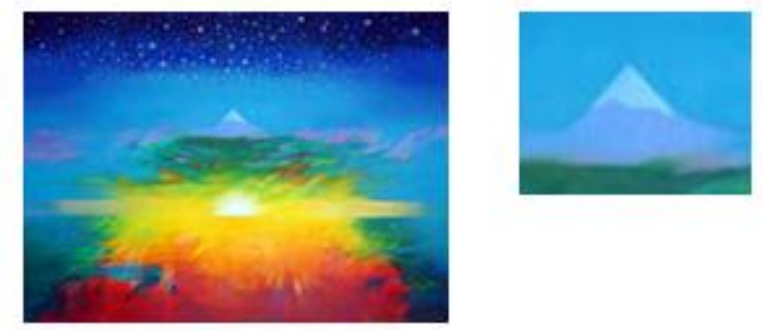

Fig. 3: Semangat Ledang (1999), Syed Ahmad Jamal, Acrylic on canvas.

\section{CONCLUSION}

To sum up, in all over the world, the combination of three main types of ordinary matters for instance, calligraphy, vegetal motifs and geometric patterns usually used in the decoration of Islamic architecture. Indeed, a message in Islam is expressed through a created art language. Therefore, in the visual artworks, shapes, symbol and meaning is best carrying the concept of Tawhid. Moreover, the representation of geometric shape is the one that constitute Oneness of Allah and unity. Clearly, the holy book Qur'an, al-Hadith and nature (physical realm) becomes the root centered and main references for the artists in produce artworks that related with the Islamic notions. Everything starts from the understanding and appreciation of all the three. Al-Quran and the physical realm is proof of the Greatness of Allah the Creator. The selection samples of visual artworks that has been analyze is identified and proven that the concept of Tawhid is applied in these visual artworks to expressed Oneness and Unity towards Contemplation to the One God (Allah) through the symbols of Geometric shape.

\section{ACKNOWLEDGMENT}

The authors would like to acknowledge Mara University of Technology (UiTM) and the people who have been helping throughout this research study. Special thanks goes to National Visual Art Gallery Malaysia, National Archive, Gallery Shah Alam, State of Museum Terengganu Malaysia, and other public and private gallery located in Malaysia.

\section{REFERENCES}

[1] Idris Saputra, N. I. M. (2014). Konsep Tauhid Dalam Padangan Haji Abdul Malik Karim Amrullah (Buya Hamka) (Doctoral Dissertation, Universitas Islam Negeri Sunan Kalijaga).
[2] Badron, M. S. (2012). Ibn Al-'Arabi on Affirming the Oneness of Allah's Divinity (Al-Tawhid). Jurnal Akidah dan Pemikiran Islam, 11(2010).

[3] Mazlina, M. A. P. D. (2011). Tawhid and its Implications for Islamic Architecture. Journal of Architecture, Planning and Construction Management, 1(2).

[4] Spahic, O. (2012). Tawhid and its implications for Islamic architecture. Journal of Architecture, Planning and Construction Management, 1(2), 21-35.

[5] HAQ, M. A. (1983). The Perspective of At-Tawhīd. Islamic Studies, 22(3), 1-19.

[6] Philips, A. A. B. (1989). The fundamentals of tawheed (Islamic monotheism). Islamic Books.

[7] Lamprecht, M. A. (2014). Exploration Of The Similarities Between The Unity Of Allah And The Unity Of The Triune God Of The Bible.

[8] Basaree, R. O. (2003). Art, Mathematics \& Philosophy: A study of the geometrical and cosmological principles in traditional malay art and design.

[9] Daud, S. A. B. W. M., Zain, D. H. B. M., \& Rahman Bin Amin, W. (2014). Study on the Malaysian Islamic Visual Art: The Contemporary View. International Journal of Education and Research, ISSN: 22016333.

[10] Sanusi, K. (2016). Encountering globalisation: the work of Sulaiman Esa from the 1950s to 2011. WIT Transactions on The Built Environment, 159, 23-34. https://doi.org/10.2495/IHA160031

[11] (Pirous. A.D, Personal Communication, November, 8, 2015)

[12] Abdullah Muhammad (Nakula). (1978). Falsafah dan pemikiran orangorang Melayu: Hubungannya dengan Islam dan Kesenian, Kuala Lumpur: Kementerian Belia dan Sukan. 